\title{
KORELASI IKLIM KERJA DENGAN KECELAKAAN KERJA DI PT JAPFA COMFEED INDONESIA TBK BATI-BATI KALIMANTAN SELATAN
}

\author{
Alfina Inayah, Tien Zubaidah, Maharso \\ Poltekkes Kemenkes Banjarmasin Jurusan Kesehatan Lingkungan \\ Jl. H.M. Cokrokusumo No. 1 A Kota Banjarbaru \\ Email: alfinainayah20@gmail.com
}

\begin{abstract}
Correlation of Work Climate With Occupational Accidents At PT Japfa Comfeed Indonesia Tbk Bati-Bati South Kalimantan. One of the working conditions that can cause health problems for workers is exposure to heat. Climate improper work may cause health problems and lead to impaired concentration of labor that resulted in accidents. This study aim to determine the relationship work climate with occupational accidents in animal feed production process unit in PT Japfa Comfeed Indonesia Tbk Batibati on Jl. A. Yani Km 35,5 Desa Nusa Indah Bati-Bati, Tanah Laut, South Kalimantan. Cross sectional study design with a total population of 30 labors and samples selected by total sampling were analyzed using Chi-Square test. The results showed that the working environment at the 1 st floor $28,69^{\circ} \mathrm{C}$, on the 2 nd floor $28,90^{\circ} \mathrm{C}$ and $3 \mathrm{rd}$ floor $30,50^{\circ} \mathrm{C}$ which means that the working climate on the 3rd floor exceeds NAB. Occupational accidents occurred on the 1 st floor of $25 \%$, the 2 nd floor of $14,3 \%$ and 3rd floor of to $63,6 \%$. From the results of the bivariate analysis using Chi-square test proved to be statistically significant relationship between work climate with the accident in unit production PT Japfa Comfeed Indonesia Tbk Bati-Bati. Efforts should be made to address the working environment exceeds the NAB is with improved ventilation and the provision of drinking water that meets the needs of labor and provision of clothes that absorb sweat like cotton.
\end{abstract}

Keywords $\quad$ : Work Climate, Occupational Accidents, PT Japfa Comfeed Indonesia Tbk

\begin{abstract}
Abstrak: Korelasi iklim kerja dengan kecelakaan kerja di PT Japfa Comfeed Indonesia Tbk Bati-Bati Kalimantan Selatan. Salah satu kondisi lingkungan kerja yang dapat menimbulkan gangguan kesehatan bagi tenaga kerja adalah paparan panas. Iklim kerja yang tidak tepat dapat menimbulkan gangguan kesehatan dan mengakibatkan gangguan konsentrasi tenaga kerja yang berakibat pada kecelakaan kerja. Penelitian ini bertujuan untuk mengetahui hubungan iklim kerja dengan kecelakaan kerja pada unit proses produksi pakan ternak di PT Japfa Comfeed Indonesia Tbk Bati-bati di Jl. A. Yani Km 35,5 Desa Nusa Indah, Kecamatan Bati-Bati, Kabupaten Tanah Laut, Kalimantan Selatan. Penelitian dengan desain Cross sectional dengan total populasi 30 tenaga kerja dan sampel dipilih secara total sampling yang dianalisis menggunakan uji Chi-Square. Hasil penelitian menunjukkan bahwa iklim kerja pada lantai $128,69^{\circ} \mathrm{C}$, pada lantai $228,90^{\circ} \mathrm{C}$ dan lantai $330,50^{\circ} \mathrm{C}$ yang artinya iklim kerja pada lantai 3 melebihi NAB. Kecelakaan kerja pada lantai 1 terjadi 25\%, lantai 2 14,3\% dan lantai 3 63,6\%. Dari hasil analisis bivariat menggunakan uji Chi-Square terbukti secara statistik ada hubungan yang bermakna antara iklim kerja dengan kecelakaan kerja di unit produksi PT Japfa Comfeed Indonesia Tbk Bati-bati. Upaya yang dapat dilakukan untuk mengatasi iklim kerja yang melebihi NAB adalah dengan perbaikan ventilasi dan penyediaan air minum yang memenuhi kebutuhan tenaga kerja serta pemberian pakaian yang menyerap keringat seperti bahan katun.
\end{abstract}

Kata kunci $\quad$ : Iklim kerja, Kecelakaan kerja, PT Japfa Comfeed Indonesia Tbk 


\section{PENDAHULUAN}

Berdasarkan UU No. 3 Tahun 1992 tentang Jaminan Sosial Tenaga Kerja Pasal 1 angka (6) yang dimaksud dengan kecelakaan kerja adalah kecelakaan yang terjadi berhubung dengan hubungan kerja, termasuk penyakit yang timbul karena hubungan kerja, demikian pula kecelakaan yang terjadi dalam perjalanan berangkat dari rumah menuju tepat kerja, dan pulang kerumah melalui jalan yang biasa atau wajar dilalui(1).

Penyebab kecelakaan dapat dibagi menjadi 2 yaitu kondisi tidak aman (unsafe condition) dan tindakan tidak aman (unsafe action). Kondisi tidak aman dapat diartikan bahwa dalam pelaksanaan kegiatan pekerjaan dilingkungan kerja seharusnya mematuhi aturan dari Industri Hygiene, yang mengatur agar kondisi tempat kerja aman dan sehat. Sedangkan tindakan tidak aman yang dimaksud adalah kegiatan tidak aman yang dilakukan oleh pekerja yang dapat membahayakan pekerja itu sendiri atau pekerja lainnya ${ }^{(2)}$

Menurut penelitian hampir $85 \%$ kecelakaan terjadi disebabkan faktor manusia yang melakukan tindakan tidak aman. Tindakan tidak aman ini dapat disebabkan oleh kurangnya pengetahuan, kurangnya keahlian, ataupun kurangnya kedisiplinan dalam bekerja (2).

International Labour Organization (ILO) pada tahun 2014 memberikan angka 29 kecelakaan kerja yang mengakibatkan kematian (kecelakaan fatal) dalam 100.000 pekerja Indonesia. ILO juga mencatat bahwa setiap tahunnya Indonesia mendapatkan 99.000 kecelakaan dengan $70 \%$ di antaranya menyebabkan kematian dan cacat seumur hidup. Kecelakaan kerja Indonesia telah membuat Negara Indonesia merugi hingga Rp. 280 Triliun(3). Dari data diatas menunjukkan bahwa kejadian kematian yang berkaitan dengan kejadian kecelakaan kerja masih tinggi dan perlu diatasi.

Dari pusat data dan informasi kementrian kesehatan RI jumlah kasus kecelakaan akibat kerja pada tahun 20122013 di Kalimantan Selatan meningkat, yaitu kecelakaan kerja pada tahun 2011 terjadi 78 kasus dan pada tahun 2013 meningkat menjadi 1651 kasus (4).

Iklim kerja yang terlalu panas dapat berakibatmeningkatnya pengeluaran cairan tubuh melalui keringat sehingga bisa terjadi dehidrasi dan gangguan kesehatan lainnya yang lebih berat menurut Tarwaka dalam Karya Tulis Ilmiah Muhammad Al-Fajar (5).

Selain dehidrasi, ada beberapa penyakit lain seperti heat cramps, heat exhaustion dan heat stroke yang biasanya ditandai dengan keluarnya keringat yang sangat berlebihan pada pekerja, tekanan darah menurun, denyut nadi lebih cepat, terasa lemah dan dapat pingsan. Pengaruh lain dari tekanan panas yang melebihi ambang batas yaitu dapat daya kerja otot karena kehilangan garam natrium sehingga terjadi kelelahan otot.

Menurut Peraturan Menteri Tenaga Kerja Dan Transmigrasi Nomor Per.13/Men/X/2011 Tahun 2011 Tentang Nilai Ambang Batas Faktor Fisika Dan Faktor Kimia Di Tempat Kerja yang dimaksud dengan Iklim kerja yaitu hasil perpaduan antara suhu, kelembaban, kecepatan gerakan udara dan panas radiasi dengan tingkat pengeluaran panas dari tubuh tenaga kerja sebagai akibat pekerjaannya (iklim kerja panas)(6).

Menurut Dinas Perindustrian dan Perdagangan Provinsi Kalimantan Selatan jumlah Unit Usaha pada tahun 2013 sebanyak 66.544 buah (2) dan PT Japfa Comfeed Indonesia unit Banjarmasin adalah salah satunya. PT Japfa Comfeed Indonesia unit Banjarmasin terletak di Kecamatan Bati-bati, Kabupaten Tanah Laut, Kalimantan Selatan merupakan salah satu perusahaan yang bergerak dibidang pengolahan produk berupa pakan ternak.

PT Japfa Comfeed Indonesia unit Banjarmasin sendiri telah menerapkan K3 dalam menjalankan kegiatan produksi, PT Japfa Comfeed Indonesia unit Banjarmasin juga telah mendapat sertifikat Zero Acident. Namun berdasarkan hasil survey pendahuluan peneliti didapat informasi bahwa terdapat kejadian kecelakaan kerja yang tidak terdokumentasi. 
Sedangkan berdasarkan hasil survey pendahuluan diketahui iklim kerja pada 2 titik dibagian produksi yaitu titik I didapat angka $29^{\circ} \mathrm{C}$ dan titik II didapat angka $29,7^{\circ} \mathrm{C}$ yang kedua titik pengukuran tersebut dilakukan di bagian panel lantai 2.

Berdasarkan hasil survey pendahuluan tersebut tampak dibeberapa tempat kerja masih ditemukan iklim kerja yang tidak memenuhi standar, maka menarik untuk diketahui hubungan iklim kerja dengan kejadian kecelakaan kerja di bagian produksi PT Japfa Comfeed Indonesia Tbk Bati-bati. Secara umum tujuan penelitian ini yaitu diketahuinya hubungan iklim kerja dengan kecelakaan kerja pada unit proses produksi pakan ternak di PT Japfa Comfeed Indonesia Tbk Bati-bati.

\section{BAHAN DAN CARA PENELITIAN}

Desain penelitian dengan metode croos sectional yaitu mengamati antar suatu kelompok dengan suatu kasus kejadian.

Populasi penelitian ini adalah tenaga kerja dan bagunan itu sendiri. Variabel yang diteliti dalam penelitian ini adalah iklim kerja dan kecelakaan kerja pada tenaga kerja. Dengan cara pengukuran ISBB pada iklim kerja dan wawancara pada tenaga kerja.

Pengumpulan data dengan cara melakukan pengukuran faktor fisika (iklim kerja) serta wawancara tenaga kerja, melihat arsip klinik perusahanaan dan hasil pengukuran sebelumnya, dan Tabel 2 Kejadian Kecelakaan Kerja di Unit Produksi PT Japfa Comfeed Indonesia Tbk

\begin{tabular}{lrrrrrrrrr}
\hline \multirow{2}{*}{$\begin{array}{c}\text { Kecelakaan } \\
\text { Kerja }\end{array}$} & \multicolumn{1}{c}{ Lantai 1 } & \multicolumn{9}{c}{ Lantai 2 } & \multicolumn{2}{c}{ Lantai 3 } & \multicolumn{2}{c}{ Total } \\
\cline { 2 - 11 } & f & \multicolumn{1}{c}{$\%$} & f & $\%$ & f & $\%$ & f & $\%$ \\
\hline Pernah & 3 & 25 & 1 & 14,3 & 7 & 63,6 & 11 & 36,7 \\
Tidak Pernah & 9 & 75 & 6 & 85,7 & 4 & 36,3 & 19 & 63,3 \\
\hline Total & 12 & 100 & 7 & 100 & 11 & 100 & 30 & 100 \\
\hline
\end{tabular}

Berdasarkan Tabel 2 dapat dilihat risiko kecelakaan kerja banyak terjadi pada lantai 3 yaitu 7 orang $(63,6 \%)$ berisiko kecelakaan kerja pada suhu ISBB referensi dari buku dan skripsi yang berkaitan. Analisis statistik dengan menggunakan statistik uji beda proporsi atau uji statistik Chi-square $\left(\mathrm{x}^{2}\right)$.

\section{HASIL DAN PEMBAHASAN Hasil}

Dari 7 lantai yang dimiliki bangunan produksi PT Japfa Comfeed Indonesia Tbk, 3 lantai dikerjakan dengan bantuan tenaga kerja, sehingga tingkat iklim kerja yang diukur hanya pada 3 lantai yaitu lantai 1,2 dan 3. Hasil pengukuran dapat dilihat pada Tabel 1 sebagai berikut:

Tabel 1 Tingkat Iklim Kerja (ISBB) di Unit Produksi PT Japfa Comfeed Indonesia Tbk Tahun 2016

\begin{tabular}{|c|c|c|c|}
\hline \multirow{2}{*}{$\begin{array}{l}\text { Iklim } \\
\text { Kerja } \\
\text { (ISBB) }\end{array}$} & \multicolumn{3}{|c|}{ Ruangan } \\
\hline & Lantai 1 & Lantai 2 & Lantai 3 \\
\hline $\begin{array}{l}\text { Hasil } \\
\text { pengukur } \\
\text { an ISBB } \\
\left({ }^{\circ} \mathrm{C}\right)\end{array}$ & 28,69 & 28,90 & 30,50 \\
\hline $\begin{array}{l}\text { Nilai } \\
\text { Ambang } \\
\text { Batas } \\
\text { (NAB) }\end{array}$ & $\begin{array}{l}\text { Memenu } \\
\text { hi } \\
\text { standar }\end{array}$ & $\begin{array}{l}\text { Memenu } \\
\text { hi } \\
\text { standar }\end{array}$ & $\begin{array}{l}\text { Tidak } \\
\text { memenu } \\
\text { hi } \\
\text { standar }\end{array}$ \\
\hline
\end{tabular}

Dari Tabel 1 terlihat bahwa unit produksi tingkat iklim kerja tertinggi terdapat pada lantai 3 yaitu $30,5^{\circ} \mathrm{C}$ (tidak memenuhi standar).

Kejadian kecelakaan kerja di Unit PT Japfa Comfeed Tbk dari wawancara 30 responden dapat dilihat pada Tabel 2 sebagai berikut: 
Tabel 3. Hubungan Iklim Kerja (ISBB) dengan Kecelakaan Kerja PT Japfa Comfeed Tbk

\begin{tabular}{ccccccccc}
\hline \multirow{2}{*}{$\begin{array}{c}\text { Iklim Kerja } \\
\text { (Nilai ISBB) }\end{array}$} & \multicolumn{4}{c}{ Kecelakaan Kerja } & \multicolumn{3}{c}{ Total } & \multirow{2}{*}{ p } \\
\cline { 2 - 7 } & Pernah & $\%$ & $\begin{array}{c}\text { Tidak } \\
\text { Pernah }\end{array}$ & $\%$ & frek & $\%$ & \\
\hline Tidak Memenuhi Standar & 7 & 23,33 & 4 & 13,33 & 11 & 36,66 & \\
Memenuhi Standar & 4 & 13,33 & 15 & 50 & 19 & 63,33 & 0,047 \\
\hline Total & 11 & 36,66 & 19 & 63,33 & 30 & 100 & \\
\hline
\end{tabular}

Berdasarkan hasil analisis menggunakan metode Chi-Square, terdapat 1 cell yang nilaianya kurang dari 5 sehingga nilai $\mathrm{p}$ yang digunakan yaitu nilai Fisher's Exact Test yaitu nilai $\mathrm{p}=$ 0,047 dan nilai $\alpha$ yang digunakan yaitu $5 \%$ atau $\alpha=0,05$. Dari hasil tersebut diperoleh hasil nilai $\mathrm{p}<\alpha$ yang artinya Ho ditolak (terbukti secara statistik ada hubungan antara iklim kerja dengan kecelakaan kerjapada unit produksi PT Japfa Comfeed Tbk).

\section{PEMBAHASAN}

Pengukuran Iklim Kerja (ISBB) dilakukan pada 3 lantai dari total 7 lantai yang ada di Unit Produksi PT Japfa Comfeed Tbk yaitu lantai 1, lantai 2 dan lantai 3 atau ruangan yang terdapat tenaga kerja. Lantai 1 pada bagging off yaitu proses intake dan packing, lantai 2 terdapat ruang kontrol dan area mixer yaitu proses grinding dan dosing, dan lantai 3 area press yaitu proses pressing.

Dari hasil pengukuran tersebut diperoleh nilai ISBB pada lantai 1 dan lantai 2 tidak melebihi NAB atau memenuhi standar yaitu lantai 1 nilai ISBB $28,69^{\circ} \mathrm{C}$ dan lantai 2 nilai ISBB 28,9 ${ }^{\circ} \mathrm{C}$ serta nilai ISBB lantai 3 melebihi NAB atau tidak memenuhi standar yang ditentukan yaitu $30,5^{\circ} \mathrm{C}$ (Tabel 1). Berdasarkan Peraturan Menteri Tenaga Kerja Dan Transmigrasi Nomor PER.13/MEN/X/2011 Tahun 2011 tentang Nilai Ambang Batas Faktor Fisika dan Faktor Kimia di Tempat Kerja nilai ISBB yang disyaratkan untuk $75 \%$ kerja $25 \%$ istirahat atau 40 jam seminggu kerja yaitu $29,0^{\circ} \mathrm{C}(7)$. Standar $\mathrm{NAB}$ inilah yang dipergunakan untuk menilai iklim kerja di unit Produksi PT Japfa Comfeed Tbk.

Tingginya nilai ISBB pada lantai 3 disebabkan kurangnya sirkulasi udara sehingga pergerakan udara lambat. Penerangan menggunakan cahaya matahari langsung dengan kontruksi jendela kaca tertutup yang dapat memantulkan panasnya matahari seperti teori efek rumah kaca. Selain itu suhu panas dari mesin yang berproduksi juga mengeluarkan radiasi panas. Setiap mesin yang berproduksi mengeluarkan radiasi. Sifat udara yang panas menjadi lebih renggang dan ringan dibanding udara dingin disekitar. Udara yang lebih ringan akan naik ke atas seperti yang telah dijelaskan oleh Ariestoteles (8). Selanjutnya material konrtuksi yang terbuat dari besi baja merupakan konduktor (penghantar) panas yang baik. Hal-hal tersebut menyebabkan suhu pada lantai 3 terasa lebih panas daripada lantai 1 dan 2.

Iklim kerja yang terlalu panas dapat berakibatmeningkatnya pengeluaran cairan tubuh melalui keringat sehingga bisa terjadi dehidrasi dan gangguan kesehatan lainnya yang lebih berat menurut Tarwaka dalam Karya Tulis Ilmiah Muhammad Al-Fajar (4).

Selain dehidrasi, ada beberapa penyakit lain seperti heat cramps, heat exhaustion dan heat stroke yang biasanya ditandai dengan keluarnya keringat yang sangat berlebihan pada pekerja, tekanan darah menurun, denyut nadi lebih cepat, terasa lemah dan dapat pingsan. Pengaruh lain dari tekanan panas yang melebihi ambang batas yaitu dapat daya kerja otot karena kehilangan garam natrium sehingga terjadi kelelahan otot.

Iklimkerja yang panas dapat mempengaruhi kondisi pekerja dan dapat menurunkan kapasitas kerja yang berakibat menurunnya efisiensi dan produktifitas kerja.Apabila paparan dibiarkan terus menerus akan 
menyebabkan kelelahan dan memperburuk kondisi pekerja.

Sebanyak 36,7 \% responden di PT Japfa Comfeed Tbk pernah mengalami kecelakaan kerja. Kecelakaan kerja terbanyak terjadi pada lantai 3 dengan presentasi kecelakaan kerja sebesar $63,7 \%$. Kecelakaan kerja yang pernah dialami yaitu terjatuh, terbentur, terpeleset, terjepit, terkena suhu yang ekstrim, memar, luka ringan dan sesak nafas.Pada lantai 3 diketahui seluruh responden pernah mengalami keluar keringat banyak namun suhu badan normal serta sering merasa kehausan dan mengatasinya dengan banyak minum. Iniartinya responden telah mengalami dehidrasi.Perusahaan telah menyediakan air minum pada setiap lantai yang dapat membantu mengendalikan dehidrasi tenaga kerja.

Berdasarkan hasil uji statistik, terbukti ada hubungan antara iklim kerja (ISBB) dengan penilaian risiko kecelakaan kerja pada unit produksi PT Japfa Comfeed Tbk.

Seperti teori yang digunakan berdasarkan faktor penyebab kecelakaan kerja, hal ini masuk kedalam faktor kondisi tidak aman (unsafe condition) atau kondisi dilingkungan kerja yang tidak aman dan membahayakan yaitu iklim kerja melebihi NAB. Selanjutnya hal ini masuk kedalam golongan penyebab dasar atau penyebab tidak langsung kecelakaan (basic cause) menurut Ramli (9).

Dilihat dari faktornya maka faktor penyebabnya ialah lingkungan fisik tempat kerja yang (iklim kerja) yang melebihi NAB. Menurut Triwibowo (10), Faktor lingkungan fisik merupakan salah satu faktor lingkungan yang memungkinkan penyebab kecelakaan kerja.

\section{KESIMPULAN DAN SARAN}

Hasil pengukuran kondisi fisik iklim kerja pada unit pakan ternak PT Japfa Comfeed Indonesia Tbk Bati-bati yaitu lantai 1 ISBB $28,69^{\circ} \mathrm{C}$, lantai 2 ISBB $28,9^{\circ} \mathrm{C}$, dan lantai 3 ISBB $30,5^{\circ} \mathrm{C}$. Artinya lantai 1 dan 2 memenuhi standar dan lantai 3 tidak memenuhi standar menurut
Peraturan Menteri Tenaga Kerja Dan Transmigrasi Nomor PER.13/MEN/X/2011 Tahun 2011 tentang Nilai Ambang Batas Faktor Fisika dan Faktor Kimia di Tempat Kerja.

Berdasarkan kejadian kecelakaan kerja pada proses produksi pakan ternak di PT Japfa Comfeed Indonesia Tbk Batibati, kecelakaan kerja terjadi $36,6 \%$ dari total 3 ruangan yang di nilai. $25 \%$ pada lantai 1, 14,3\% pada lantai 2 dan 63,6\% pada lantai 3. Artinya lantai 3 memiliki kejadian kecelakaan paling tinggi.

Berdasarkan hasil analisis statistik Chi-Square hubungan iklim kerja dengan kecelakaan kerja pada proses produksi pakan ternak di PT Japfa Comfeed Indonesia Tbk Bati-bati yaitu Ho ditolak. Artinya ada hubungan antara iklim kerja dengan kecelakaan kerja pada unit produksi PT Japfa Comfeed Tbk.

Dapat disarankan untuk perusahaan agar lebih memperhatikan keadaan iklim kerja dandapat memenuhi kebutuhan air minum bagi tenaga kerja, melakukan perbaikan ventilasi dan pemberian APD berupa baju berbahan menyerap keringat seperti bahan katun kepada seluruh tenaga kerja.

\section{KEPUSTAKAAN}

1. Indonesia, Presiden Republik.UndangUndang N0.13 Tahun 2003 Tentang Ketenagakerjaan. Jakarta : s.n., 2003.

2. Aditama, Candra Yoga.Kesehatan dan Keselamatan Kerja. Jakarta : Penerbit Universitas Indonesia, 2002.

3. Supriyadi, Agung. 2014.Infografik: Data dan Fakta Keselamatan dan Kesehatan Kerja di Indonesia.

http://katigaku.id/2014/08/24/infogr afik-data-dan-fakta-keselamatan-dankesehatan-kerja-di-indonesia/

4. Direktorat Bina Kesehatan Kerja dan Olahraga, Kementrian Kesehatan, 2014. Kasus Kecelakaan Akibat Kerja. Kalimantan Selatan

5. Al-Fajar, Muhammad .2014. Penerapan APD di Unit Packing PT Japfa Comfeed Indonesia Tbk. Banjarmasin: Politeknik Kesehatan Negeri Banjarmasin.

6. Peraturan Mentri Tenaga Kerja dan Transmigrasi. 2011. Menteri Tenaga Kerja Dan Transmigrasi Nomor 
PER.13/MEN/X/2011 Tahun 2011tentang Nilai Ambang Batas Faktor Fisika dan Faktor Kimia di Tempat Kerja. Jakarta.

7. Keputusan Menteri Tenaga Kerja. 1999. Keputusan Menteri Tenaga Kerja No. 51 Tahun 1999 Tentang Nilai Ambang Batas Faktor Fisika Di Tempat kerja. Jakarta.

8. Masdiisya. Sifat Udara Panas. 2011. https://masdiisya.wordpress.com/201 1/01/09/sifat-udara-panas/

9. Ramli, Soehatman.Sistem Manajemen Keselamatan dan Kesehatan Kerja OHSAS 18001. Jakarta : Dian Rakyat, 2010.

10. Triwibowo, Cecep.Kesehatan Lingkungan dan K3. Yogyakarta : Nuha Medika, 2013. 